\title{
A buried Tertiary pluton in East Greenland?
}

\author{
DAVID W. MATTHEWS
}

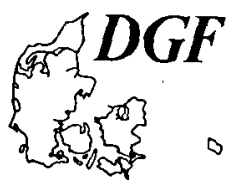

Matthews, D. W.: A buried Tertiary pluton in East Greenland? Bull. geol. Soc. Denmark, vol. 28, pp. 17-20, Copenhagen. October 23rd, 1979. https://doi.org/10.37570/bgsd-1979-28-04

The discovery of steeply tilted basalts in Watkins Bjerge suggests the presence of a buried pluton. The implications of this for the erosional history of the area are considered.

David W. Matthews, 46 Port Hill Gardens, Shrewsbury, England, February 2nd, 1979.

A recently explored area of several square kilometres at the head of Rosenborg Glacier in central East Greenland shows several notable features, described here. It lies in the Watkins Mountains, a central part of the East Greenland flood basalt terrain, and includes Gunnbjørns Fjeld (3700 m. approx.) - the highest peak in Greenland. The late Professor Wager was the first to approach the area (in the 1930's) and he referred to the "stupendous south wall of the Watkins Bjerge « (1947); he estimated a total thickness of some $2.5 \mathrm{~km}$ for the almost horizontal basalt strata seen there, overlying tuffs and late Cretaceous sediments in Korridoren and adjacent areas to the west.

An Anglo-Danish expedition was, in 1971, the first to travel up Rosenborg Glacier and reach the deep cwm right underneath the south wall to which Wager referred. Seen close to, the cliffs are, if anything, even more impressive and are uncompromisingly vertical for about $2 \mathrm{~km}$., consisting of regular near-horizontal strata throughout. Wager originally (in Watkins, 1932) suggested that some of these exceptional cliffs might be fault scarps, but the idea was subsequently discarded. It is supported now by the finding, in several low-lying spurs at the foot of the cliffs, of lavas with steep and apparently random angles of dip.

\section{Results}

The sketch map in figure 1 shows the disposition of outcrops of tilted lava, while figure 2 shows their typical appearance. Exposure varies from good to very poor due to the patchy but fre- quently heavy covering of scree and to the friable nature of the rock, but nowhere could actual folds be observed. The tilted lavas appear to form large fault blocks several hundred metres across, each at a different angle. Vertical strata were seen in the most easterly outcrops (fig. 1). These random dips persist in two places to within a few hundred metres of the base of the main cliffs. Elsewhere, faults could be observed at the foot of the cliffs, marked only by the change in relief with no accompanying change in dip.

A further occurrence of tilted lavas, isolated from those in Rosenborg Glacier, was found in buttresses about $5 \mathrm{~km}$ further west, towards Korridoren which Wager visited in 1935. This occurrence, only visible from certain angles, is apparently more regular, a single large block showing a constant south-westerly dip $\left(40^{\circ}\right.$ approx.) over at least $1 \mathrm{~km}$ of ridge. Its margins were not seen.

Explanation of these finds must be largely conjectural until the area can be examined in more detail. The following additional observations from Rosenborg Glacier are, however, pertinent.

i) The tilted basalts appear to be the normal tholeiitic basalt lithology of the type that forms the whole of the main flood basalt succession in the region. Red flow tops and ashy layers are common. Some exposures show rather more alteration than normal and a few are clearly oxidised.

ii) Some coarsely brecciated lava was found, both as loose material and in situ, but with uncertain disposition and origin.

iii) Although the tilted basalts are, typically vesicular, it appears that the vesicles tend to be 
empty, whereas those in the surrounding horizontal basalts are normally filled with quartz and chalcedony. High up in the main basalt sequence, for instance near the top of Gunnbjørns Fjeld, the vesicles also tend to be empty; a feature taken (Brooks, 1979) to indicate proximity to the top surface of the original lava plateau.

iv) A large dyke-like body cutting the tilted lavas at one point consists of coarse pyroxene-rich olivine gabbro, a fresh plutonic lithology quite unknown in the extrusive sequence or in later sills.

v) No actual flexuring of the lavas has been seen.

\section{Discussion and Conclutions}

Conclusions drawn from this limited evidence are as follows. Firstly, the areas of differing dip must be separated from each other by faults, the lavas having been broken up into a number of tilted fault blocks. There is no positive evidence of volcanism associated with the faulting, but the breccia may be at least in part, volcanic in origin. The boundary between tilted lavas and the surrounding cliffs is also in all probability faulted, the fracture following an arcuate line as shown in figure 1 . Vertical subsidence on this fracture could be substantial, possibly as much as $2 \mathrm{~km}$, but its age and full extent are not known.

The predominantly low relief of the tilted lava areas could be due to the steeper dips or to the more altered nature of at least some of the flows. Their low topographic level at the foot of huge cliffs could be due, at least in part, to original subsidence along the postulated marginal fault. This could originally have caused the formation of a physical crater in the lava plateau when faulting took place. The apparent absence of vesicle fillings favours subsidence from a higher level in the basalt pile.

It is suggested that the most probable explanation of all these features is that there is a still-buried Tertiary pluton under the area at the head of Rosenborg Glacier. Its roof thickness would originally have been $2-2,5 \mathrm{~km}$ and probably several hundred metres of lava roof still exist below glacier level. The schematic representation of Skaergaard given in McBirney (1975), in which the roof of the intrusion is shown as a

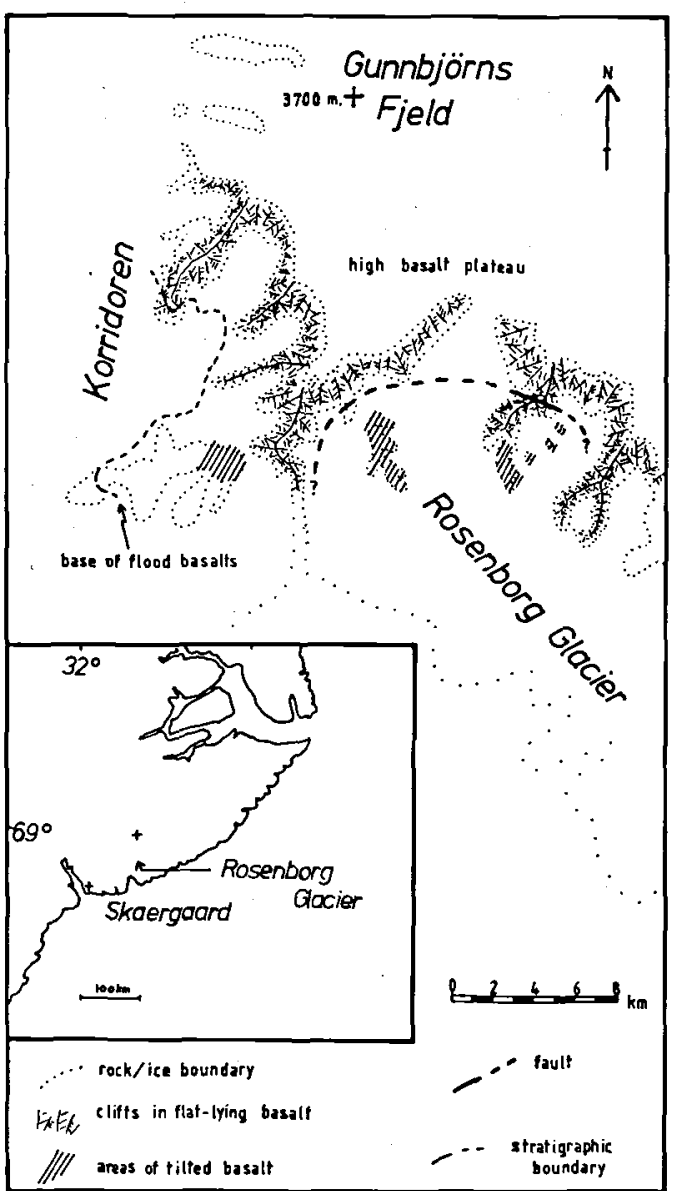

Fig. 1. Sketch map of the area around the head of Rosenborg Glacier, showing areas of tilted lavas and postulated faults.

number of tilted and down-faulted blocks, is the sort of situation envisaged. This type of roof structure is commonly inferred for many passively emplaced plutons, often with associated surface volcanism, though the extent of the volcanism is seldom made clear. Major Tertiary plutons exposed near to Rosenborg Glacier are Lilloise Bjerge and Borgtindern. Both have been emplaced to a high structural level in the basalt pile and are now deeply eroded, but both show traces of basalt roof inferred, in the case of Lilloise, to have been som 2 to $3 \mathrm{~km}$ thick (Sheppard et. al., 1977).

If, in fact, the emplacement of plutons such as Lilloise and Borgtindern and that proposed at »Rosenborg " produced deep craters in the basalt plateau surface at an early stage of its evolution, 


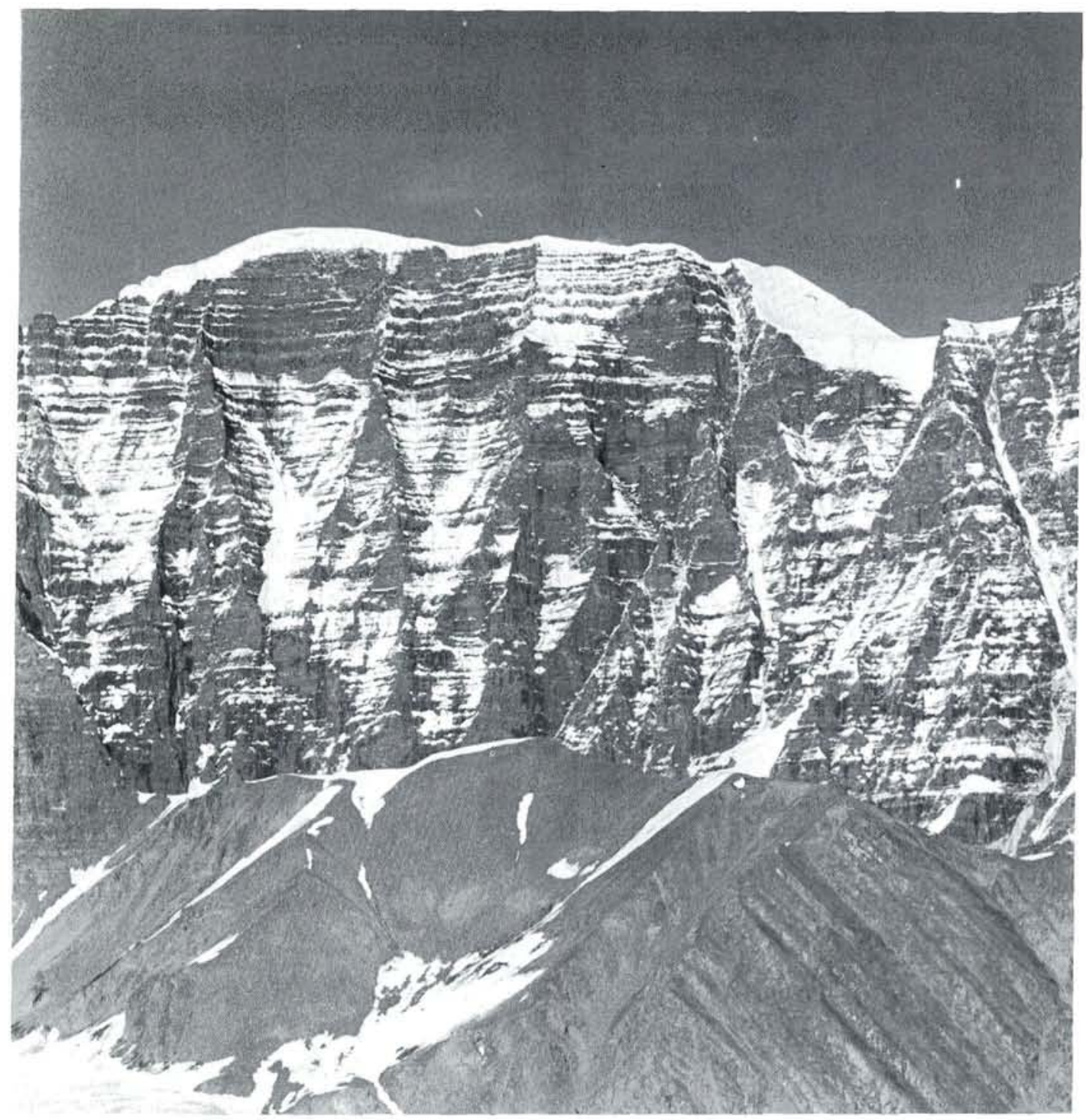

Fig. 2. Tilted basalts adjacent to $2 \mathrm{~km}$ high cliffs of horizontal strata in north east corner of Rosenborg Glacier.

these would clearly have had a major influence on the development of the Rosenborg and adjacent Kronborg Glacier valleys. Once uncovered, the hard plutonic rocks of Lilloise and Borgtindern have withstood further erosion better than the surrounding basalts and have formed spectacular Alpine-type peaks. In contrast to this, Brooks (1979) proposes that to the south and west of Skaergaard (which is approximately $100 \mathrm{~km}$ south west of Rosenborg Glacier), where the overall level of erosion is much deeper, there is evidence that the plutons and their roof rocks have, throughout their history, shown greater resistance to erosion than their surroundings. $\mathrm{He}$ suggests that their presence may originally have been marked on the plateau surface by overlying volcanic cones.

Hopes of distinguishing between these two possibilities or of relating them to the chronological and magmatic distinctions already established in the East Greenland Tertiary province are, at present, slim. The critical areas are extremely remote. Similarly, geomorphological information on the inception and development of postvolcanic 
erosion is scarce and very difficul to enlarge upon. Late surface volcanism is so far known only at Prinsen af Wales Bjerge, along the edge of the ice cap, where alkaline lavas overly the main basalt pile. The chances of finding further evidence bearing on these problems, such as crater infilling or traces of late volcanism, appear best in the Prinsen af Wales and central Watkins Bjerge areas where the present level of erosion is not yet too deep.

Acknowledgements. The author thanks the members and supporters of Watkins Mountains Expedition, 1971, during which these observations were made.

\section{Dansk sammendrag}

I den centrale del af det tertiære plateau basalt område i Østgrønland omkring den øvre del af Rosenborg Gletscher (Wat- kins Bjerge) er stærkt hældende plateau basalt blottet. Dele af en cirkulær randforkastning afgrænser området med disse basalter fra de næsten horisontale plateau basalter. Randforkastningen og basalternes haldning tilskrives blokforkastning under indsynkning over en dybereliggende tertiær intrusion.

\section{References}

Brooks, C. K. 1979: Geomorphological observations at Kangerdlugssuak, East Greenland. Meddr Gronland, Geosci, 1, in press.

McBirney, A. R. 1975: Differentiation of the Skaergaard intrusion. Nature 253: 691-694.

Sheppard, S. M. F., Brown, P. E. \& Chambers, A. D. 1977: The Lilloise intrusion. East Greenland: Hydrogen isotope evidence for the efflux of magmatic water into the contact metamorphic aureole. Contrib. Mineral. Petrol. 63: 129-147.

Wager, L. R. 1947: Geological investigations in East Greenland, Pt. IV. The stratigraphy and tectonics of Knud Rasmussens Land and the Kangerdlugssuak region. Meddr. Gronland 134, (5): 1-62.

Watkins, H. G. 1932: The British Arctic Air-route Expedition 1930-31. Geogr. J. 79: 353-367 \& 466-501. 